\title{
Does isotretinoin have an effect on glucose metabolism, insulin growth factor-I and insulin-like growth factor-3 binding protein?
}

\author{
Czy izotretynoina wpływa na metabolizm glukozy, insulinowy czynnik wzrostu I \\ i białko wiążące insulinopodobny czynnik wzrostu 3?
}

Esra Inan Doğan

Department of Dermatology, School of Medicine, Adıyaman University, Adiyaman, Turkey

Dermatol Rev/Przegl Dermatol 2021, 108, 361-37|

DOI: https://doi.org/l0.51|4/dr.2021.113154

\section{CORRESPONDING AUTHOR/} ADRES DO KORESPONDENCJI:

Assist. Prof. Esra Inan Doğan Department of Dermatology

School of Medicine

Adıyaman University

Adiyaman, Turkey

Phone: +90 5538529420

E-mail: esranander@yahoo.com

\section{ABSTRACT}

Introduction: Isotretinoin is the only effective agent at all stages of acne vulgaris, but its effects on certain systems remain unkown.

Objective: To evaluate the effects of isotretinoin and other acne treatments on insulin growth factor-1 (IGF-1), insulin-like growth factor-3 binding protein (IGFBP-3), insulin, C-peptide, glucose and glycated hemoglobin $\mathrm{A}_{1 \mathrm{c}}\left(\mathrm{HbA}_{1 \mathrm{c}}\right)$, and HOMA-IR.

Material and methods: Eighty one patients with acne vulgaris were divided into two groups: the first group was treated with isotretinoin and the second group treated with systemic minocycline and topical benzoyl peroxide (in combined treatment). IGF-1, IGFBP3, insulin, HOMA-IR, C-peptide, glucose and $\mathrm{HbA}_{1 \mathrm{c}}$ serum levels were assessed in two groups.

Results: IGFBP-3 levels were significantly increased in patients receiving isotretinoin treatment for 3 months. When isotretinoin and combined treatment groups were compared, a significant rise in the IGF-1 level was found in the combined treatment group. Unlike the literature, our results showed that the commonly used acne treatments did not change the serum levels of IGF-1, insulin, C-peptide, glucose and $\mathrm{HbA}_{1 \mathrm{c}}$ significantly.

Conclusions: Consequently, we showed that isotretinoin did not impair glucose metabolism in patients who were previously not obese or insulin resistant. Since IGF-1, IGFBP-3 parameters have effects on cell growth and proliferation, we suggest that they play an effective role in acne pathogenesis and treatment mechanism.

Key words: isotretinoin, insulin, glucose, insulin growth factor-1, insulin-like growth factor-3 binding protein.

\section{STRESZCZENIE}

Wprowadzenie: Izotretynoina jest jedynym lekiem, który jest skuteczny w leczeniu wszystkich stadiów trądziku zwykłego, jednak jego potencjalne oddziaływanie na różne układy organizmu może nie być w pełni poznane.

Cel pracy: Ocena wpływu izotretynoiny i innych leków przeciwtrądzikowych na insulinowy czynnik wzrostu 1 (IGF-1), białko wiążące insu- 
linopodobny czynnik wzrostu 3 (IGFBP-3), insulinę, peptyd C, glukozę, hemoglobinę glikowaną $\left(\mathrm{HbA}_{1 \mathrm{c}}\right)$ oraz wskaźnik HOMA-IR.

Materiał i metody: Łącznie 81 pacjentów z trądzikiem zwykłym podzielono na dwie grupy. Pacjenci z pierwszej grupy byli leczeni izotretynoiną, natomiast $\mathrm{w}$ drugiej grupie wprowadzono terapię skojarzoną obejmującą miejscowe stosowanie nadtlenku benzoilu i leczenie ogólne minocykliną. W obu grupach oznaczano stężenia IGF-1, IGFBP-3, insuliny, peptydu C, glukozy i $\mathrm{HbA}_{1 \mathrm{c}}$ oraz określano wskaźnik HOMA-IR.

Wyniki: Po 3 miesiącach stosowania izotretynoiny stężenie IGFBP-3 było znamiennie podwyższone. Porównanie grupy leczonej izotretynoiną i otrzymującej leczenie skojarzone wykazało znamienny wzrost stężenia IGF-1 w grupie leczonej w sposób skojarzony. W przeciwieństwie do doniesień literaturowych uzyskane przez nas wyniki pokazują, że powszechnie stosowane leczenie przeciwtrądzikowe nie zmienia w sposób znamienny stężenia IGF-1, insuliny, peptydu C, glukozy i $\mathrm{HbA}_{1 \mathrm{c}}$ w surowicy.

Wnioski: W badaniu wykazano, że izotretynoina nie powoduje upośledzenia metabolizmu glukozy u pacjentów, u których wcześniej nie występowała otyłość lub insulinooporność. Natomiast parametry IGF-1 i IGFBP-3 mogą odgrywać istotną rolę w patogenezie i mechanizmie leczenia trądziku.

Słowa kluczowe: izotretynoina, insulina, glukoza, insulinowy czynnik wzrostu 1, białko wiążące insulinopodobny czynnik wzrostu 3.

\section{INTRODUCTION}

Acne vulgaris is inflammatory dermatosis that has several mechanisms in pathogenesis; follicular epidermal hyperproliferation, increased sebum production, inflammation and effects of Cutibacterium acnes. Isotretinoin is the only effective drug at all these stages [1]. Few hormones affecting sebaceous gland activity have been a relationship with acne. These are insulin, insulin-like growth factor 1 (IGF-1), insulin-like growth factor 3 protein (IGFBP-3) [2].

Eye function, reproduction, metabolism, growth and differentiation of various cell types, apoptosis, and carcinogenesis are the functions of retinoids $[3,4]$.

Retinoic acid (RA) and its metabolites have an important share in the mechanism of insulin sensitivity [5]. It is believed that the effect of 13-cis-retinoic acid is transformed to all-trans-retinoic acid (ATRA) by isomerization and is attached to RA retinoid receptors. RA arranges gene expression by activating specific members of the transcription factor superfamily called nuclear hormone receptors [2, 6]. Several studies showed that several RA isomers increase peroxisome proliferator-activated receptors (PPARS), causing insulin resistance $[7,8]$. Besides, activating PPARS, RA may also serve as a ligand for the nuclear receptor PPAR B-5. This receptor is suggested to be associated with the genes involved in glucose metabolism [8].

\section{WPROWADZENIE}

Trądzik zwykły (acne vulgaris) jest dermatozą zapalną, której patogeneza obejmuje kilka mechanizmów. Należą do nich: hiperproliferacja komórek w ujściach mieszków włosowych, wzmożone wydzielanie łoju, stan zapalny oraz działanie bakterii Cutibacterium acnes. Izotretynoina jest jedynym lekiem, który cechuje się skutecznością w leczeniu wszystkich stadiów trądzika [1]. Niewiele hormonów wpływających na aktywność gruczołów łojowych ma związek z trądzikiem. Należą do nich: insulina, insulinopodobny czynnik wzrostu 1 (IGF-1) oraz białko wiążące insulinopodobny czynnik wzrostu 3 (IGFBP-3) [2].

Wśród różnych funkcji retinoidów należy wymienić wpływ na czynność narządu wzroku, układ rozrodczy i metabolizm, a także wzrost i różnicowanie różnych typów komórek, apoptozę i kancerogenezę [3, 4].

Kwas retinowy (retinoic acid - RA) i jego metabolity odgrywają istotną rolę w mechanizmie wrażliwości organizmu na insulinę [5]. Uważa się, że kwas 13-cis-retinowy przekształca się w procesie izomeryzacji w kwas all-trans-retinowy (ATRA) oraz przyłącza do receptorów retinoidowych RA. RA reguluje ekspresję genów poprzez aktywację swoistych związków należących do nadrodziny czynników transkrypcyjnych określanych jako jądrowe receptory hormonalne $[2,6]$. W kilku badaniach wykazano, że niektóre izomery RA wzmagają 
There are several research studies evaluating the effect of isotretinoin on glucose metabolism [9]. It has been reported that short-term isotretinoin treatment does not affect insulin sensitivity [2]. There are studies reporting that long-term treatment may affect insulin tolerance negatively, therefore glucose and glycated hemoglobin $\left(\mathrm{HbA}_{1 \mathrm{c}}\right)$ parameters in acne patients [2, 7]. In a research study, 10-day RA treatment modified adipose tissue of rats [10]. Contradictory results were found in these studies.

This information shows that isotretinoin therapy may lead to disruption in insulin sensitivity, however this issue has been indirectly researched $[7,11]$. However, individuals with high levels of several serum parameters are at higher risk of metabolic syndrome in older ages [2].

IGFBP-3, IGF-1 have very different roles in cell proliferation, protein synthesis, carbohydrate homeostasis. IGFBP-3 is the most abundant IGFBP in blood and also has have a very high binding rate for IGF-1 and IGF-2 [4, 12]. It has been known that IGFBP-3 blocks IGF effect and inhibits cell growth [13].

Androgenic effect is important in acne in the peripubertal period, however, the course and prognosis of acne is more related to growth hormone and IGF-1 levels rather than androgens [14, 15]. In addition, the production of adrenal and peripheral androgen signals by the androgen receptor is increased by IGF-1. It was reported that growth and proliferation in sebaceous glands and lipogenesis in these glands is upregulated by IGF-1 as a result of the effect of IGF-1 on the sterol response element binding protein-1 [15].

Recently, it has been suggested that IGF-1 plays an important role in the acne pathogenesis. There are many research studies on the IGF system, and their effects on cellular proliferation and survival. Current data show the genetic modification in insulin/IGF1 ratio [16]. There is little information about the mechanism of acne treatment on IGF-1 physiology in the past studies.

We investigated whether acne treatments could modulate IGF-1, IGFBP-3, insulin, C-peptide, HOMA$\mathrm{IR}$, glucose and $\mathrm{HbA}_{1 \mathrm{c}}$ levels, and whether these parameters have an effect on acne pathogenesis by comparing isotretinoin and combined therapies.

\section{OBJECTIVE}

Given the above mentioned mechanisms, the aim of our study is to evaluate the effects of isotretinoin and other acne treatments on IGF-1, IGFBP-3, and insulin, C-peptide, glucose, insulin resistance showing $\mathrm{HOMA}-\mathrm{IR}$ and $\mathrm{HbA}_{1 \mathrm{c}}$.

\section{MATERIAL AND METHODS}

Eighty-four patients with acne were involved in the research. 3 of these 84 people did not finish the aktywność receptorów aktywowanych proliferatorami peroksysomów (peroxisome proliferator-activated receptors - PPARS), co powoduje insulinooporność [7, 8]. Poza aktywacją PPARS, RA może również służyć jako ligand dla receptora jądrowego PPAR B-5. Postulowano także, że receptor ten ma związek z genami uczestniczącymi w metabolizmie glukozy [8].

W piśmiennictwie można znaleźć kilka badań analizujących wpływ leczenia izotretynoiną na metabolizm glukozy [9]. Na podstawie dostępnych doniesień krótkotrwała terapia izotretynoiną nie wpływa na wrażliwość na insulinę [2]. Są również badania wskazujące, że długotrwałe leczenie może negatywnie wpływać na tolerancję insuliny, a także na parametry glukozy i hemoglobiny glikowanej $\left(\mathrm{HbA}_{1 \mathrm{c}}\right) \mathrm{u}$ pacjentów $\mathrm{z}$ trądzikiem [2, 7]. W jednym z badań zaobserwowano, że 10-dniowe leczenie RA modyfikuje tkankę tłuszczową u szczurów [10]. W dostępnych w literaturze badaniach stwierdzono jednak sprzeczne wyniki.

Ze zgromadzonych danych wynika, że leczenie izotretynoiną może prowadzić do zaburzenia wrażliwości na insulinę. Zagadnienie to było jednak badane wyłącznie pośrednio [7, 11]. Wiadomo jednak, że osoby, u których występuje podwyższone stężenie niektórych parametrów w surowicy, są bardziej narażone na ryzyko wystąpienia zespołu metabolicznego w starszym wieku [2].

IGFBP-3 i IGF-1 pełnią bardzo odmienne funkcje w procesach proliferacji komórek, syntezy białek i homeostazy węglowodanów. IGFBP-3 jest najbardziej powszechnie występującym białkiem IGFBP we krwi. Charakteryzuje się bardzo wysokim stopniem wiązania IGF-1 i IGF-2 [4, 12]. Wykazano, że IGFBP-3 blokuje działanie IGF oraz hamuje wzrost komórek [13].

Androgeny istotnie wpływają na trądzik w okresie okołopokwitaniowym, jednak przebieg i rokowanie w trądziku wykazuje silniejszą zależność ze stężeniem hormonu wzrostu i IGF-1 niż z androgenami [14, 15]. Ponadto IGF-1 nasila wytwarzanie nadnerczowych i obwodowych sygnałów androgennych przez receptor androgenowy. Wskazywano również, że IGF-1 pobudza wzrost i proliferację oraz lipogenezę w gruczołach łojowych w wyniku oddziaływania IGF-1 na białko wiążące sekwencję odpowiedzi na sterole 1 (SREBP-1) [15].

Ostatnio pojawiały się doniesienia postulujące, że IGF-1 może odgrywać znaczącą rolę w patogenezie trądziku. W piśmiennictwie można znaleźć liczne publikacje dotyczące wpływu systemu IGF na proliferację i przeżywalność komórek. Aktualne dane wskazują na rolę modyfikacji genetycznych we wskaźniku insulina/ IGF-1 [16]. W dotychczas opublikowanych badaniach dostępnych jest niewiele danych o wpływie leczenia przeciwtrądzikowego na fizjologiczne działanie IGF-1.

W naszym badaniu, poprzez porównanie leczenia izotretynoiną z terapią skojarzoną, przeanalizowano, czy leczenie przeciwtrądzikowe może modulować stężenia 
study. Therefore, there were 81 patients in the final analysis and divided into two groups by acne severity: 57 patients were divided according to Global Acne Grading System (GAGS) into moderate (grade II), severe (grade III) and very severe acne (grade IV), 24 of them were divided into moderate and severe acne. Among these two groups, systemic RA was initiated in the first group, and topical benzoyl peroxide and minocycline treatment was initiated in the second group. The research consisted of patients who were examined in the dermatology clinic between October 2020 and February 2021. The diagnosis of acne was made by an experienced dermatologist. Each group was treated in accordance with recent clinical EDF guidelines and acne severity [17].

The first study group consisted of men and nonpregnant women aged 18 to 42 years with moderate, severe and very severe nodulocystic acne if they were unsuccessfully treated with topical drugs and tetracyclines. These patients with the following criteria were not accepted to the study: previous oral retinoid treatments, any diseases that may affect the hormone profile, and any serious systemic disorders, any diseases that could affect pancreas and insulin, c-peptide and glucose level. Isotretinoin treatment was began at a dose of $0.75 \mathrm{mg} / \mathrm{kg} /$ day and, was continued to $0.85 \mathrm{mg} / \mathrm{kg} /$ day as a basic dose after 1 month. Biochemical and hormonal parameters were screened just before baseline (pre-treatment) and after 3 months of isotretinoin treatment (post-treatment). Somatomedin (IGF-1), IGF-BP3, $\mathrm{HbA}_{1 \mathrm{c}^{\prime}}$ fasting glucose, C-peptide, insulin parameters were measured. Homeostasis Model Assessment of Insulin Resistance (HOMA-IR) and body mass index (BMI) were calculated. The second group consisted of 24 patients who received topical benzoyl peroxide treatment and minocycline $100 \mathrm{mg} /$ day for 3 months in the moderate and severe group. Biochemical and hormonal parameters such as somatomedin (IGF-1), IGFBP-3, $\mathrm{HbA}_{1 c^{\prime}}$ fasting glucose, $\mathrm{C}$-peptide, and insulin were screened and measured post-treatment. HOMA-IR value and BMI value were calculated.

This study protocol was approved by the local ethics committee (approval number: 2020/9-21). Each patient gave written informed consent.

\section{Statistical analysis}

Statistical analysis were performed with SPSS software version 22.0. All numerical variables were expressed as mean \pm SD or median, maximum, minimum values. The normality of the data was analyzed by Kolmogorov-Smirnov test. Wilcoxon signed-rank test was used for initial and final value analysis of hormonal and biochemical data before and after Isotretinoin treatment in those with nonhomogeneous variability. Group 1 and group 2 were compared by Mann-Whitney $U$ test.
IGF-1, IGFBP-3, insuliny, peptydu C, glukozy i $\mathrm{HbA}_{1 \mathrm{c}}$ oraz wskaźnik HOMA-IR, a także czy wymienione parametry mają znaczenie $\mathrm{w}$ patogenezie trądziku.

\section{CEL PRACY}

Uwzględniając opisane powyżej mechanizmy, celem badania była ocena wpływu izotretynoiny i innych preparatów przeciwtrądzikowych na stężenia IGF-1, IGFBP-3, insuliny, peptydu C, glukozy oraz insulinooporność wyrażoną wskaźnikiem HOMA-IR i stężeniem $\mathrm{HbA}_{1 \mathrm{c}}$.

\section{MATERIA $~ I$ METODY}

Do badania włączono 84 pacjentów z trądzikiem. Trzech pacjentów z tej grupy nie ukończyło badania. W ostatecznej analizie uwzględniono 81 pacjentów, których podzielono na dwie grupy w zależności od stopnia nasilenia trądziku: 57 pacjentów zaliczono do grupy o umiarkowanym, ciężkim i bardzo ciężkim (odpowiednio stopień II, III i IV) przebiegu trądziku według skali GAGS (Global Acne Grading System), a 24 pacjentów do grupy o umiarkowanym i ciężkim nasileniu schorzenia. W pierwszej grupie wprowadzono ogólne leczenie izotretynoiną, a w drugiej - minocykliną i miejscowo nadtlenkiem benzoilu. Do badania zakwalifikowano pacjentów, którzy zgłosili się do poradni dermatologicznej od października 2020 do lutego 2021 roku. Rozpoznanie trądziku ustalał doświadczony dermatolog. Chorych w każdej grupie leczono zgodnie z najnowszymi wytycznymi klinicznymi European Dermatology Forum (EDF) w zależności od stopnia nasilenia choroby [17].

Pierwszą grupę badaną stanowili pacjenci w wieku od 18 do 42 lat, z umiarkowanym, ciężkim i bardzo ciężkim trądzikiem guzkowo-torbielowatym, u których wcześniej stosowano leki miejscowe i antybiotyki z grupy tetracyklin, bez poprawy. Kryteria wyłączenia z badania obejmowały: ciążę, wcześniejsze doustne leczenie retinoidami, występowanie choroby potencjalnie wpływającej na profil hormonalny oraz choroby ogólnoustrojowe wpływające na trzustkę, stężenie insuliny, peptydu C i glukozę. Leczenie izotretynoiną rozpoczęto od dawki 0,75 mg/kg m.c./dobę, a po miesiącu zwiększono do $0,85 \mathrm{mg} / \mathrm{kg}$ m.c. (dawka podstawowa). Parametry biochemiczne i hormonalne oznaczano tuż przed rozpoczęciem leczenia (,przed leczeniem”) oraz po 3 miesiącach terapii izotretynoiną („po leczeniu”). U pacjentów oznaczono stężenia somatomedyny (IGF-1), IGFBP-3, $\mathrm{HbA}_{1 c^{\prime}}$ glukozy na czczo, peptydu C oraz insuliny. Obliczono także wskaźnik HOMA-IR (Homeostasis Model Assessment of Insulin Resistance) oraz wskaźnik masy ciała (body mass index - BMI). Druga grupa obejmowała 24 pacjentów z trądzikiem o nasileniu umiarkowanym 
Spearman correlation analysis was made for correlation analysis of acne duration, acne severity and hormonal and biochemical parameters.

\section{RESULTS}

In our study, there were 57 acne patients (44 (77.2\%) females, $13(22.8 \%)$ males) in the isotretinoin group and 24 acne patients (15 (62.5\%) females and $9(37.5 \%)$ males) in the combined treatment group. No statistically significant change was found with regard to age and sex $(p>0.05)$. In patients receiving combined treatment, acne severity was stage II (moderate) in $12(50.0 \%)$ patients, stage III (severe) in 12 (50\%) patients, and in the isotretinoin group, acne severity was stage II in 25 (43.85\%) patients, stage III in 25 (43.85\%) patients, and stage IV in $7(12.2 \%)$ patients.

The mean age of the patients on combined treatment was $22.60 \pm 3.61$, and $21.45 \pm 2.92$ on isotretinoin treatment.

Hormonal and biochemical parameters of the first group pre-isotretinoin treatment and post-isotretinoin treatment were shown in table 1 . When the post-treatment values were compared with the pretreatment levels, IGFBP-3 and BMI levels increased statistically significantly $(p<0.05)$. The mean IGF-1 level decreased after the treatment, but this decrease was not statistically significant. No significant differences were found in insulin, HOMA-IR, $\mathrm{HbA}_{1{ }^{\prime}}$ glucose, C-peptide between pretreatment and posttreatment $(p>0.05)$.

The patients on 3 months of isotretinoin and combination treatment were compared in table 2 . When two groups were compared, no significant difference was found between the two groups in insulin, $\mathrm{HbA}_{1 \mathrm{c}^{\prime}}$ glucose, IGFBP-3,, C-peptide, HOMA-IR and BMI levels. However, IGF-1 level decreased significantly in the isotretinoin group $(p<0.05)$.

A positive correlation was found between disease duration and disease severity in patients followed up with a diagnosis of acne. No correlation was found between disease severity and biochemical values, somatomedin (IGF-1), IGFBP-3, $\mathrm{HbA}_{1 \mathrm{c}}$, fasting glucose, $\mathrm{C}$-peptide, insulin and between disease duration and biochemical and hormonal values (table 3).

A negative correlation was found between IGF-1 and IGFBP-3 levels. A negative correlation was found between BMI and IGF-1, IGFBP-3 values and positive correlation was found between BMI and glucose, $\mathrm{HbA}_{1 \mathrm{c}}$ (tab. 4).

\section{DISCUSSION}

Isotretinoin is a vitamin A analogue that has been prescribed in acne treatment since 1982 [8]. There i ciężkim, u których leczono minocykliną w dawce $100 \mathrm{mg} /$ dobę przez 3 miesiące i miejscowo nadtlenkiem benzoilu. Parametry biochemiczne i hormonalne, m.in. stężenie somatomedyny (IGF-1), IGFBP-3, $\mathrm{HbA}_{1 c^{\prime}}$ glukozy na czczo, peptydu $\mathrm{C}$ i insuliny oznaczano podczas oceny przesiewowej, a następnie po zakończeniu leczenia. Obliczono wartości wskaźników HOMA-IR i BMI.

Protokół badania został zatwierdzony przez miejscową komisję bioetyczną (decyzja nr 2020/9-21). Każdy pacjent wyraził pisemną świadomą zgodę na udział w badaniu.

\section{Analiza statystyczna}

Analizę statystyczną przeprowadzono za pomocą oprogramowania SPSS w wersji 22.0. Wszystkie zmienne liczbowe wyrażono w postaci średniej \pm odchylenie standardowe (SD) lub jako medianę, wartość maksymalną i minimalną. Zgodność rozkładu analizowanych zmiennych z rozkładem normalnym badano testem Kołmogorowa-Smirnowa. Do analizy początkowych i końcowych wartości parametrów hormonalnych i biochemicznych przed leczeniem i po leczeniu izotretynoina $\mathrm{w}$ przypadku niejednorodnej zmienności zastosowano test Wilcoxona dla par obserwacji. Grupę 1. i 2. porównano za pomocą testu U Manna-Whitneya. W celu określenia zależności między czasem trwania trądziku, nasilenia choroby oraz parametrów hormonalnych i biochemicznych wykorzystano analizę korelacji Spearmana.

\section{WYNIKI}

W naszym badaniu grupa leczona izotretynoiną liczyła 57 pacjentów z trądzikiem $(44$ (77,2\%) kobiety, 13 (22,8\%) mężczyzn). Grupa otrzymująca leczenie skojarzone minocykliną i nadtlenkiem benzoilu obejmowała 24 pacjentów z trądzikiem (15 (62,5\%) kobiet i 9 (37,5\%) mężczyzn). Nie stwierdzono statystycznie znamiennych różnic pod względem wieku i płci $(p>0,05)$. W grupie leczonej izotretynoiną trądzik stopnia II (umiarkowany) stwierdzono u $25(43,85 \%)$ pacjentów, stopnia III (ciężki) u 25 (43,85\%) pacjentów, a stopnia IV u 7 (12,2\%) pacjentów. W grupie otrzymującej leczenie skojarzone trądzik stopnia II i III występował odpowiednio u 12 (50,0\%) i 12 (50\%) pacjentów.

Średnia wieku pacjentów otrzymujących leczenie skojarzone wynosiła 22,60 $\pm 3,61$ roku, a leczonych izotretynoiną 21,45 $\pm 2,92$ roku.

Parametry hormonalne i biochemiczne w pierwszej grupie przed rozpoczęciem leczenia izotretynoiną oraz po jej zakończeniu przedstawiono w tabeli 1. Porównanie stężenia IGFBP-3 i wartości wskaźnika BMI po leczeniu i przed leczeniem wskazuje, że nastąpił ich statystycznie znamienny wzrost $(p<0,05)$. Średnie stężenie IGF-1 zmniejszyło się po leczeniu, ale redukcja ta nie była znamienna statystycznie. Nie stwierdzono 
Table I. Biochemical and hormonal values before and after isotretinoin treatment

Tabela I. Wartości parametrów biochemicznych i hormonalnych przed leczeniem i po leczeniu izotretynoiną

\begin{tabular}{|c|c|c|c|}
\hline Parameter/Parametr & $\begin{array}{l}\text { Pre-treatment (group I)/Przed } \\
\text { leczeniem (pacjenci z I. grupy) }\end{array}$ & $\begin{array}{c}\text { Post-treatment (ISO) } \\
\text { (group I)/Po leczeniu (IZO) } \\
\text { (pacjenci z I. grupy) }\end{array}$ & $\begin{array}{c}\text { P-value/ } \\
\text { Wartośc } P\end{array}$ \\
\hline$|\mathrm{GF}-|[\mathrm{ng} / \mathrm{ml}]$ & $251.53(98-420)$ & 225.15 ( I I3-339.0) & 0.27 \\
\hline IGFBP-3 [ng/ml] & $476 \mid(1530-6520)$ & $5011(1290-7070)$ & 0.024 \\
\hline BMI $\left[\mathrm{kg} / \mathrm{m}^{2}\right]$ & $22.38(19.12-26.20)$ & $22.72(19.72-26.41)$ & 0.022 \\
\hline $\begin{array}{l}\text { Fasting blood glucose/Stężenie glukozy } \\
\text { we krwi na czczo [mg/dl] }\end{array}$ & $82.51(68-108)$ & $81.61(7 \mid-98)$ & 0.55 \\
\hline Insulin/Insulina [IU/ml] & $10.84(2.70-61.32)$ & $11.92(2.4 \mid-60.4)$ & 0.46 \\
\hline C-peptide/Peptyd C [ng/ml] & $1.97(0.66-5.10)$ & $2.27(0.88-8.82)$ & 0.33 \\
\hline HOMA-IR & $2.24(0.5|-| 1.20)$ & $2.31(0.5 \mid-8.0)$ & 0.27 \\
\hline $\mathrm{HbA}$ & $4.89(4.10-5.9)$ & $4.84(4.00-5.85)$ & 0.46 \\
\hline
\end{tabular}

BMI - body mass index, HOMA-IR - Homeostasis Model Assessment of Insulin Resistance, $\mathrm{HbA}_{\mathrm{lc}}$ - hemoglobulin $\mathrm{A}_{1 \mathrm{c}}$. Values are median (minimum-maximum range). Analyzed by Wilcoxon signed-rank test.

BMI - wskaźnik masy ciała, HOMA-IR - wskaźnik HOMA-IR (Homeostasis Model Assessment of Insulin Resistance), HbA wyrażone jako mediana (zakres od wartości minimalnej do maksymalnej). Analiza przy użyciu testu Wilcoxona dla par obserwacji.

Table 2. Comparison of biochemical and hormonal values of pretreatment and after combined therapy with minocycline and benzoyl peroxide

Tabela 2. Porównanie wartości parametrów biochemicznych i hormonalnych przed leczeniem i po leczeniu skojarzonym (minocykliną i nadtlenkiem benzoilu

\begin{tabular}{|c|c|c|c|}
\hline Parameter/Parametr & $\begin{array}{l}\text { Pre-treatment (group 2)/ } \\
\text { Przed leczeniem (pacjenci } \\
\text { z 2. grupy) }\end{array}$ & $\begin{array}{l}\text { Post-treatment (combined therapy) (group 2)/ } \\
\text { Po leczeniu (skojarzonym) (pacjenci z 2. grupy) }\end{array}$ & $\begin{array}{l}\text { P-value/ } \\
\text { Wartośc } p\end{array}$ \\
\hline IGF-I [ng/ml] & $294.99(168-410)$ & $297.2(|78-4| 6)$ & 0.48 \\
\hline IGFBP-3 [ng/ml] & $4962(3720-7820)$ & $4964(3730-7700)$ & 0.80 \\
\hline $\mathrm{BMI}\left[\mathrm{kg} / \mathrm{m}^{2}\right]$ & $21.86(19.20-25.60)$ & $21.97(19.40-25.90)$ & 0.43 \\
\hline $\begin{array}{l}\text { Fasting blood glucose/Stężenie } \\
\text { glukozy we krwi na czczo [mg/dl] }\end{array}$ & $82.79(72-91)$ & $82.29(7 \mid-90)$ & 0.11 \\
\hline Insulin/Insulina [IU/ml] & $7.12(3.90-11.70)$ & $7.16(3.90-12.70)$ & 0.084 \\
\hline C-peptide/Peptyd C [ng/ml] & $1.96(1.29-4.24)$ & $1.94(1.29-4.24)$ & 0.10 \\
\hline HOMA-IR & $1.45(0.5 I-8.0)$ & $1.60(0.79-2.60)$ & 0.23 \\
\hline $\mathrm{HbA}_{\mathrm{lc}}$ & $5.09(4.30-6.0)$ & $5.03(4.30-6.00)$ & 0.91 \\
\hline
\end{tabular}

BMI - body mass index, HOMA-IR - Homeostasis Model Assessment of Insulin Resistance, HbA range). Analyzed by Wilcoxon signed-rank test.

BMI - wskaźnik masy ciała, HOMA-IR - wskaźnik HOMA-IR (Homeostasis Model Assessment of Insulin Resistance), HbA ${ }_{l c}-h^{2}$ hoglobina $A_{l c}$. Wartości wyrażone jako mediana (zakres od wartości minimalnej do maksymalnej). Analiza przy użyciu testu Wilcoxona dla par obserwacji.

are several researches investigating the effects of isotretinoin on glucose metabolism. In this research, no significant change was found in IGF-1, insulin, C-peptide, $\mathrm{HbA}_{1 c^{\prime}}$ glucose levels, or HOMA-IR during isotretinoin therapy but significant increase was found in IGFBP-3 levels and BMI during isotretinoin treatment.

Literature studies found different results in the studies reporting the effects of retinoid treatment on insulin resistance and glucose metabolism. Koistinen et al. used hyperinsulinemic-euglycemic clamp technique, and treated 11 patients for 5 months with isotretinoin, and reported that insulin sensitivity decreased and an artificial insulin resistance cases również istotnych różnic pod względem stężenia insuliny, $\mathrm{HbA}_{1 c^{\prime}}$ glukozy, peptydu C oraz wskaźnika HOMA-IR przed leczeniem i po leczeniu $(p>0,05)$.

Porównanie pacjentów leczonych przez 3 miesiące izotretynoiną i otrzymujących leczenie skojarzone przedstawiono w tabeli 2. Porównanie grup nie wykazało znamiennych różnic pod względem stężenia insuliny, $\mathrm{HbA}_{1 c^{\prime}}$ glukozy, IGFBP-3, peptydu C, wartości wskaźników HOMA-IR i BMI. Stwierdzono jednak znamienne zmniejszenie stężenia IGF-1 w grupie otrzymującej izotretynoinę $(p<0,05)$.

U pacjentów z rozpoznaniem trądziku wykazano dodatnią zależność pomiędzy czasem trwania choroby i jej nasileniem. Nie stwierdzono zależności między 
Table 3. Comparison of biochemical and hormonal values of isotretinoin and combined therapy (minocycline and benzyl peroxide)

Tabela 3. Porównanie wartości parametrów biochemicznych i hormonalnych w grupie otrzymującej leczenie izotretynoiną i leczenie skojarzone minocykliną i nadtlenkiem benzoilu

\begin{tabular}{|c|c|c|c|}
\hline Parameter/Parametr & $\begin{array}{c}\text { Isotretinoin (group I)/ } \\
\text { Izotretynoina (pacjenci z I. grupy) }\end{array}$ & $\begin{array}{c}\text { Combined therapy (group 2)/ } \\
\text { Leczenie skojarzone (pacjenci z 2. grupy) }\end{array}$ & $\begin{array}{l}\text { P-value/ } \\
\text { Wartośc } p\end{array}$ \\
\hline IGF-I [ng/ml] & $225.15(113-339.0)$ & $297.2(|78-4| 6)$ & 0.039 \\
\hline IGFP3 [ng/ml] & $501 \mid(1290-7070)$ & 4964 (3730-7700) & 0.79 \\
\hline BMI $\left[\mathrm{kg} / \mathrm{m}^{2}\right]$ & $22.72(19.72-26.41)$ & $21.97(19.40-25.90)$ & 0.41 \\
\hline $\begin{array}{l}\text { Fasting blood glucose/Stężenie } \\
\text { glukozy we krwi na czczo [mg/dl] }\end{array}$ & $81.6 \mid(7 \mid-98)$ & $82.29(7 \mid-90)$ & 0.40 \\
\hline Insulin/Insulina [IU/mI] & $11.92(2.41-60.4)$ & $7.16(3.90-12.70)$ & 0.41 \\
\hline C-peptide/Peptyd C [ng/ml] & $2.27(0.88-8.82)$ & $1.94(1.29-4.24)$ & 0.73 \\
\hline HOMA-IR & $2.31(0.5 \mid-8.0)$ & $1.60(0.79-2.98)$ & 0.45 \\
\hline $\mathrm{HbA}_{\mathrm{Ic}}$ & $4.84(4.00-5.85)$ & $5.03(4.30-6.00)$ & 0.07 \\
\hline
\end{tabular}

BMI - body mass index, HOMA-IR - Homeostasis Model Assessment of Insulin Resistance, $\mathrm{HbA}_{\mathrm{lc}}$ - hemoglobulin $\mathrm{A}_{1 c^{\prime}}$ Values are median (minimum-maximum range). Analyzed by Mann-Whitney $U$ test.

BMI - wskaźnik masy ciała, HOMA-IR - wskaźnik HOMA-IR (Homeostasis Model Assessment of Insulin Resistance), HbA żone jako mediana (zakres od wartości minimalnej do maksymalnej). Analiza przy zastosowaniu testu U Manna-Whitneya.

Table 4. The correlation analysis between disease duration, global acne score, and hormonal and biochemical parameters in acne vulgaris Tabela 4. Analiza zależności między czasem trwania choroby, ogólnym nasileniem trądziku oraz wartościami parametrów hormonalnych i biochemicznych u pacjentów z trądzikiem

\begin{tabular}{|c|c|c|c|c|c|c|c|c|c|c|c|}
\hline & & BMI & IGF-I & IGFP3 & $\begin{array}{l}\text { Insulin/ } \\
\text { Insulina }\end{array}$ & $\begin{array}{l}\text { Glucose/ } \\
\text { Glukoza }\end{array}$ & $\begin{array}{l}\text { C-peptide/ } \\
\text { Peptyd C }\end{array}$ & $\mathrm{HbA}_{\mathrm{Ic}}$ & $\begin{array}{c}\text { Acne score/ } \\
\text { Ocena } \\
\text { stopnia } \\
\text { nasilenia } \\
\text { trądziku }\end{array}$ & $\begin{array}{c}\text { Acne } \\
\text { duration/ } \\
\text { Czas trwania } \\
\text { trądziku }\end{array}$ & HOMA-IR \\
\hline \multirow[t]{2}{*}{ IGF-I } & $r$ & -0.454 & & & & & & & & & \\
\hline & $p$ & $<0.001$ & & & & & & & & & \\
\hline \multirow[t]{2}{*}{ IGFP3 } & $r$ & -0.324 & 0.606 & & & & & & & & \\
\hline & $p$ & 0.014 & $<0.001$ & & & & & & & & \\
\hline \multirow[t]{2}{*}{ Insulin/Insulina } & $r$ & -0.044 & 0.159 & 0.122 & & & & & & & \\
\hline & $p$ & 0.744 & 0.238 & 0.365 & & & & & & & \\
\hline \multirow{2}{*}{$\begin{array}{l}\text { Glucose/ } \\
\text { Glukoza }\end{array}$} & $r$ & 0.391 & -0.211 & -0.120 & 0.311 & & & & & & \\
\hline & $p$ & 0.003 & 0.115 & 0.375 & 0.018 & & & & & & \\
\hline \multirow{2}{*}{$\begin{array}{l}\text { C-peptide/ } \\
\text { Peptyd C }\end{array}$} & $r$ & -0.045 & 0.114 & 0.125 & 0.698 & 0.238 & & & & & \\
\hline & $p$ & 0.738 & 0.398 & 0.354 & $<0.001$ & 0.075 & & & & & \\
\hline \multirow[t]{2}{*}{$\mathrm{HbA}_{\mathrm{Ic}}$} & $r$ & 0.390 & -0.120 & -0.123 & 0.343 & 0.815 & 0.257 & & & & \\
\hline & $p$ & 0.003 & 0.374 & 0.361 & 0.009 & $<0.001$ & 0.054 & & & & \\
\hline \multirow{2}{*}{$\begin{array}{l}\text { Acne score/ } \\
\text { Ocena stopnia } \\
\text { nasilenia } \\
\text { trądziku }\end{array}$} & $r$ & -0.115 & -0.088 & -0.142 & 0.025 & 0.077 & -0.049 & 0.097 & & & \\
\hline & $p$ & 0.394 & 0.516 & 0.293 & 0.855 & 0.568 & 0.718 & 0.472 & & & \\
\hline \multirow{2}{*}{$\begin{array}{l}\text { Acne duration/ } \\
\text { Czas trwania } \\
\text { trądziku } \\
\text { [month/ } \\
\text { miesiąc] }\end{array}$} & $r$ & -0.157 & 0.100 & 0.012 & 0.002 & 0.131 & 0.088 & 0.063 & 0.680 & & \\
\hline & $p$ & 0.242 & 0.458 & 0.929 & 0.989 & 0.331 & 0.516 & 0.640 & $<0.001$ & & \\
\hline \multirow[t]{2}{*}{ HOMA-IR } & $r$ & 0.012 & 0.159 & 0.118 & 0.933 & 0.480 & 0.655 & 0.492 & -0.021 & -0.004 & \\
\hline & $p$ & 0.932 & 0.238 & 0.384 & $<0.001$ & $<0.001$ & $<0.001$ & $<0.001$ & 0.879 & 0.979 & \\
\hline
\end{tabular}

Analyzed by Spearmann correlation.

Na podstawie analizy korelacji Spearmana. 
have been created [7]. Heliövaara et al. reported insulin resistance by using oral glucose tolerance test in 23 acne patients to assess the effect of isotretinoin treatment. They studied the patients 3 months before and directly after isotretinoin treatment and 1 month after treatment discontinuation [5]. We also determined that insulin and C-peptide levels did not change after the treatment, as they reported and also the literature showed diabetes mellitus reports suggesting to be induced by isotretinoin treatment [18]. The authors found a transient and slight reduction in insulin sensitivity evaluated by HOMA-IR in cases given acitretin for 30 days [19]. These reports do not explain the pathophysiology of this event, but they report that treatment of isotretinoin influences insulin sensitivity as it decreases or does not change $[2,5,7]$.

On a diet-induced mouse model of obesity and insulin resistance, Berry et al. found that RA administration to obese mice leads to loss of fat mass and improves glucose intolerance [20]. They found that hepatic steatosis characterized with hepatic lipid accumulation completely improved by RA therapy. As opposed to this, RA was administered to non-obese rats parenterally, and blood insulin and glucose levels were assessed [21]. The researchers found no variabilities in insulin or glucose levels after treatment.

Ethnic differences and eating habits in the patient group may explain the differences in insulin sensitivity during isotretinoin treatment in other studies. Several researchers have reported that insulin resistance increases during isotretinoin treatment, however, other researchers did not find a significant rise during isotretinoin treatment, as in our study $[2,4,8,16]$ However, in our study, an increase was identified in the mean HOMA-IR after isotretinoin treatment.

Similarly to the study by Ertuğrul et al. [2], our data showed that isotretinoin treatment did not cause any change in HOMA-IR value and glucose metabolism in acne patients, but also no significant difference was found between isotretinoin treatment and minocycline and benzoyl peroxide combined treatment. In this context, this is the first study comparing the combination treatment with isotretinoin treatment that is most commonly used in acne treatment.

IGF-1 rises to highest levels during the accelerated development period of adolescence. Protein intake increases IGF-1 levels in humans independently of total calorie consumption, and IGF-1 production is affected by genetic regulation, time of day, age, sex, exercise, stress level, nutritional status and BMI, disease status, ethnicity, and estrogen status [22].

IGF-1 may have a very important role in the acne mechanism by supporting sebocyte growth, lipid synthesis of sebaceous glands, and androgen production [23]. The importance of IGF-1 in the acne mechanism shows that acne vulgaris is an IGF-1-mediated dis- nasileniem choroby i wartościami parametrów biochemicznych, stężeniem somatomedyny (IGF-1), IGFBP-3, $\mathrm{HbA}_{1 c^{\prime}}$ glukozy na czczo, peptydu $\mathrm{C} \mathrm{i}$ insuliny oraz między czasem trwania choroby i wartościami parametrów biochemicznych oraz hormonalnych (tab. 3).

Stwierdzono ujemną zależność między stężeniem IGF-1 i IGFBP-3. Ponadto wykazano ujemną korelację między wartością BMI i stężeniem IGF-1 oraz IGFBP-3, a także dodatnią zależność między wartością BMI i stężeniem glukozy oraz $\mathrm{HbA}_{1 \mathrm{c}}$ (tab. 4).

\section{OMÓWIENIE}

Izotretynoina jest analogiem witaminy A, który jest wykorzystywany w leczeniu pacjentów z trądzikiem już od 1982 roku [8]. Wpływ leczenia izotretynoiną na metabolizm glukozy był analizowany w kilku badaniach. $\mathrm{W}$ przeprowadzonym przez nas badaniu nie stwierdzono znamiennej różnicy pod względem stężeń IGF-1, insuliny, peptydu C, $\mathrm{HbA}_{1 c^{\prime}}$ glukozy i wartości wskaźnika HOMA-IR w związku z leczeniem, jednak wykazano istotny wzrost stężenia IGFBP-3 i wartości BMI podczas leczenia.

W piśmiennictwie dostępne są prace przedstawiające różny wpływ terapii retinoidami na insulinooporność i metabolizm glukozy. Koistinen i wsp. wykorzystali metodę hiperinsulinemicznej euglikemicznej klamry metabolicznej podczas analizy 11 pacjentów leczonych przez 5 miesięcy izotretynoiną. Badacze stwierdzili obniżenie wrażliwości na insulinę oraz przypadki insulinooporności [7]. W celu oceny efektu leczenia izotretynoiną, Heliövaara i wsp. analizowali insulinooporność na podstawie wyników doustnego testu tolerancji glukozy u 23 pacjentów z trądzikiem [5]. Oznaczenia wykonano 3 miesiące przed terapią izotretynoiną, bezpośrednio po terapii oraz po miesiącu od zakończenia terapii. Stężenie insuliny i peptydu C nie zmieniło się po leczeniu, podobnie jak w naszym badaniu. $W$ piśmiennictwie dostępne są także doniesienia wskazujące, że leczenie izotretynoiną może indukować cukrzycę [18]. Autorzy stwierdzili nieznaczne przejściowe osłabienie wrażliwości na insulinę oceniane na podstawie wskaźnika HOMA-IR u pacjentów leczonych acytretyną przez 30 dni [19]. Dostępne doniesienia nie wyjaśniają patofizjologii tego zjawiska, ale wskazują, że terapia izotretynoiną wpływa na insulinowrażliwość (np. poprzez jej obniżenie) lub nie wywołuje takich zmian $[2,5,7,17]$.

Berry i wsp. stwierdzili na modelu mysim otyłości i insulinooporności wywołanych dietą, że podawanie RA otyłym myszom prowadzi do utraty masy tłuszczowej i wpływa korzystnie na nietolerancję glukozy [20]. Badacze zaobserwowali, że leczenie RA całkowicie wyeliminowało stłuszczenie wątroby charakteryzujące się odkładaniem lipidów $\mathrm{w}$ tym narządzie. $\mathrm{W}$ innym badaniu RA podawano pozajelitowo nieotyłym szczurom, a następnie analizowano stężenie insuliny i glukozy we 
ease [24]. Cappel et al. observed the correlation between IGF-1 serum levels and acne; and IGF-1 has been found to increase more during acne in women [25].

Rahaman et al. found a significant change in the mean plasma level of IGF-1 between acne and control group, and a positive relationship between acne severity and IGF-1 level and IGF-1 levels are reported to be increased more in men than in women [14].

Karadağ et al. showed that the IGF-1 level was significantly reduced with isotretinoin treatment. We could not find a connection between the severity of acne and IGF-1 values and no significant decrease in IGF-1 values during isotretinoin treatment, we can explain that by the fact that the most of our patients were women.

Serum IGF-1 decreased after topical or systemic treatment in our study. Interestingly, our study shows that commonly used treatments for acne may alter the systemic pathway of IGF-1 but it was not statistically significant. However, we showed that IGF-1 reduced significantly in the isotretinoin treatment group as compared to the combined treatment group. This suggests an indirect effect of isotretinoin treatment on IGF-1.

Unlike the results of Karadağ et al. [4], our results determine that there was no statistically significant variation in IGF-1 serum levels after isotretinoin treatment. We suggest that this difference is associated with the different environmental factors, especially diet; this issue should be investigated in the future.

Our results show that the IGFBP-3 level increased after isotretinoin treatment, however, there is no decrease in IGF-1 serum levels. It is suggested that IGFBP-3 acts by separating free IGFs, or possibly through a novel IGF-independent mechanism. It exerts antiproliferative effects in several cell types by blocking the ability of IGF-1 and IGF-2 to activate IGF1R (stimulating cell proliferation) [26]. This suggests that an increase in IGFBP-3 after RA therapy shows its effect by inhibiting the growth and proliferation of sebum cells.

These contradictory results show that more evidence-based studies are required on RA, glucose metabolism and insulin resistance. More studies are needed in obese and insulin-resistant individuals to prove our opinion that isotretinoin may change adipose tissue and insulin metabolism in individuals.

The most important deficiencies in our study were the insufficient number of patients, the fact that it was performed in a single center and the follow-up after the end of the treatment was insufficient.

\section{CONCLUSIONS}

We determined that isotretinoin did not impair glucose metabolism in patients who were previously krwi [21]. Nie stwierdzono różnic pod względem stężenia insuliny i glukozy po zakończeniu leczenia.

Za różnice we wrażliwości na insulinę w trakcie leczenia izotretynoiną mogą odpowiadać różnice etniczne i nawyki żywieniowe w analizowanej grupie pacjentów. W kilku badaniach donoszono o nasileniu insulinooporności podczas terapii izotretynoina, jednak $\mathrm{w}$ innych analizach - podobnie jak w naszym badaniu - nie stwierdzono znamiennego wzrostu insulinooporności podczas leczenia izotretynoiną $[2,4,8,16]$. W przeprowadzonym przez nas badaniu wykazano natomiast wzrost średniej wartości HOMA-IR po zakończeniu terapii izotretynoiną.

Podobnie jak w badaniu Ertuğrul i wsp. [2] zgromadzone przez nas dane wskazuja, że leczenie izotretynoiną nie powoduje zmiany wartości HOMA-IR oraz nie wpływa na metabolizm glukozy u pacjentów z trądzikiem. Ponadto nie stwierdzono znamiennej różnicy między terapią izotretynoiną i leczeniem skojarzonym minocykliną i nadtlenkiem benzoilu. Należy podkreślić, że jest to $\mathrm{w}$ tym aspekcie pierwsze badanie porównujące terapię skojarzoną z leczeniem izotretynoiną, czyli najczęściej stosowane metody terapii trądziku.

Najwyższe stężenie IGF-1 obserwowane jest w fazie przyspieszonego rozwoju w okresie dojrzewania. Spożycie białka podwyższa stężenie IGF-1 u ludzi, niezależnie od całkowitego spożycia kalorii. Wytwarzanie IGF-1 zależy od regulacji genetycznej, pory dnia, wieku, płci, aktywności fizycznej, poziomu stresu, odżywienia, BMI, stanu zdrowia, pochodzenia etnicznego i stężenia estrogenów [22].

IGF-1 może odgrywać bardzo istotną rolę w mechanizmie rozwoju trądziku poprzez pobudzanie wzrostu sebocytów, syntezę lipidów w gruczołach łojowych oraz wytwarzanie androgenów [23]. Znaczenie IGF-1 w mechanizmie powstawania trądziku wskazuje, że trądzik zwykły należy do chorób regulowanych przez IGF-1 [24]. Cappel i wsp. zaobserwowali zależność pomiędzy stężeniem IGF-1 w surowicy i trądzikiem; stwierdzono ponadto, że stężenie IGF-1 podczas trądziku jest bardziej podwyższone u kobiet [25].

Rahaman i wsp. odnotowali istotną zmianę pod względem średniego stężenia IGF-1 w osoczu pomiędzy grupą pacjentów z trądzikiem i grupą kontrolną, a także dodatnią zależność pomiędzy stopniem nasilenia trądziku i stężeniem IGF-1, przy czym stężenia IGF-1 są częściej podwyższone u mężczyzn niż u kobiet [14].

Karadağ i wsp. wykazali, że stężenie IGF-1 podczas leczenia izotretynoiną znamiennie się zmniejsza. W naszym badaniu nie udało się potwierdzić zależności między nasileniem trądziku i wartościami IGF-1. Nie stwierdzono znamiennego zmniejszenia wartości IGF-1 podczas terapii izotretynoiną. Być może odpowiada za to skład badanej grupy (większość analizowanej grupy stanowiły kobiety).

W naszym badaniu stężenie IGF-1 w surowicy zmniejszyło się po leczeniu w obu badanych grupach. 
not obese or insulin resistant. To find a more obvious result, the study should be made especially in people who are obese or already have insulin resistance, such as polycystic ovary syndrome. Multicenter clinical trials with a larger number of patients are required in order to determine the effects of isotretinoin therapy on insulin resistance and glucose metabolism. In addition, we think that IGF-1 and IGFBP-3 parameters play an active role in the pathogenesis of acne, based on their effect on cell growth and proliferation.

\section{CONFLICT OF INTEREST}

The author declares no conflict of interest.
Interesującym faktem jest, że nasze badanie wskazuje, że powszechnie stosowane metody terapii trądziku mogą wpływać na ogólnoustrojowy szlak działania IGF-1, mimo że efekt ten nie był znamienny statystycznie. Wykazaliśmy jednak znamienne zmniejszenie stężenia IGF-1 w grupie leczonej izotretynoiną w porównaniu z grupą leczoną w sposób skojarzony. Sugeruje to pośredni wpływ leczenia izotretynoiny na IGF-1.

W przeciwieństwie do wyników przedstawionych w pracy Karadağ i wsp. [4] w przeprowadzonym przez nas badaniu nie pojawiła się statystycznie znamienna różnica w stężeniu IGF-1 w surowicy po zastosowaniu leczenia izotretynoiną. Naszym zdaniem różnica ta ma związek z czynnikami środowiskowymi, zwłaszcza sposobem odżywiania. Zagadnienie to wymaga jednak dalszych wnikliwych badań.

Uzyskane przez nas wyniki wskazują na wzrost stężenia IGFBP-3 po leczeniu izotretynoiną. Nie zaobserwowano natomiast redukcji stężenia IGF-1 w surowicy. Sugeruje się, że IGFBP-3 działa poprzez oddzielanie wolnych IGF lub być może na drodze innego mechanizmu, niezależnego od IGF. Wywiera efekt antyproliferacyjny w kilku typach komórek poprzez blokowanie zdolności IGF-1 i IGF-2 do aktywacji IGF1R (pobudzania proliferacji komórek) [26]. Sugeruje to, że wzrost stężenia IGFBP-3 po leczeniu RA powoduje hamowanie wzrostu i proliferacji komórek łojowych.

Te sprzeczne wyniki pokazują, że niezbędne są kolejne oparte na dowodach badania analizujące RA, metabolizm glukozy i insulinooporność. Potrzebne są dalsze badania prowadzone u osób z otyłością i insulinoopornością, aby zweryfikować, czy izotretynoina może oddziaływać na tkankę tłuszczową i metabolizm insuliny.

Wśród głównych ograniczeń naszego badania należy wymienić stosunkowo niewielką liczbę uczestników, jednoośrodkowy charakter badania, a także brak wystarczająco kompleksowej obserwacji uczestników po zakończeniu badania.

\section{WNIOSKI}

Nasze badanie wykazało, że izotretynoina nie powoduje upośledzenia metabolizmu glukozy u pacjentów, u których wcześniej nie występowała otyłość lub insulinooporność. Aby bardziej szczegółowo zbadać tę zależność, należałoby przeprowadzić badanie $\mathrm{u}$ osób otyłych lub ze stwierdzoną insulinoopornością, np. pacjentek z zespołem policystycznych jajników. W celu określenia wpływu leczenia izotretynoiną na insulinooporność i metabolizm glukozy, niezbędne są wieloośrodkowe badania kliniczne $\mathrm{z}$ udziałem większej liczby pacjentów. Na podstawie wpływu IGF-1 i IGFBP-3 na wzrost i proliferację komórek uważamy, że parametry te odgrywają aktywną rolę $\mathrm{w}$ patogenezie trądziku. 


\section{KONFLIKT INTERESÓW}

Autor nie zgłasza konfliktu interesów.

\section{References}

Piśmiennictwo

1. Layton A.: The use of isotretinoin in acne. Dermatoendocrinology 2009, 1, 162-169.

2. Ertugrul D.T., Karadag A.S., Tutal E, Akin K.O.: Isotretinoin does not induce insulin resistance in patients with acne. Clin Exp Dermatol 2010, 36, 124-128.

3. Lotan R.: Retinoids and apoptosis: implication for cancer chemoprevention and therapy. J Natl Cancer Inst 1995, 87, $1655-1657$.

4. Karadag A.S., Ertugrul D.T., Tutal E., Akin K.O.: Short-term isotretinoin treatment decreases insulin-like growth factor-1 and insulin-like growth factor binding protein-3 levels: does isotretinoin affect growth hormone physiology? Br J Dermatol 2010, 162, 798-802.

5. Heliovaara M.K., Remitz A., Reitamo S., Teppo A.M., Karonen S.L., Ebeling P.: 13-cis-retinoic acid therapy induces insulin resistance, regulates inflammatory parameters, and paradoxically increases serum adiponectin concentration. Metabolism 2007, 56, 786-791.

6. Chambon P.: A decade of molecular biology of retinoic acid receptors. FASEB J 1996, 10, 940-954.

7. Koistinen H.A., Remitz A., Koivisto V.A., Ebeling P.: Paradoxical rise in serum adiponectin concentration in the face of acid induced insulin resistance 13-cis-retinoic. Diabetologia 2006, 49, 383-386.

8. Soyuduru G., Özsoy Adisen E., Özer İ., Aksakal B.A.: The effect of isotretinoin on insulin resistance and adipocytokine levels in acne vulgaris patients. Turk J Med Sci 2019, 49, 238-244.

9. Tsai T.Y., Liu H.W., Chao Y.C., Huang Y.C.: Effects of isotretinoin on glucose metabolism in patients with acne: a systematic review and meta-analysis. J German Soc Dermatol 2020, 18, 539-545.

10. Krskova-Tybitanclova K., Macejova D., Brtko J., Baculikova M., Krizanova O., Zorad S.: Short term 13-cis-retinoic acid treatment at therapeutic doses elevates expression of leptin, GLUT4, PPARgamma and aP2 in rat adipose tissue. J Physiol Pharmacol 2008, $59,731-743$.

11. Dicembrini I., Bardini G., Rotella C.M.: Association between oral isotretinoin therapy and unmasked latent immunomediated diabetes. Diabetes Care 2009, 32, e99.

12. Valentinis B., Bhala A., DeAngelis T., Baserga R., Cohen P.: The human insulin-like growth factor (IGF) binding protein-3 inhibits the growth of fibroblasts with a targeted disruption of the IGF-I receptor gene. Mol Endocrinol 1995, 9, 361-367.

13. Friedrich N., Haring R., Nauck M., Ludemann J., Rosskopf D., Splicke-Liss E., et al.: Mortality and serum insulin-like growth factor (IGF)-I and IGF binding protein 3 concentrations. J Clin Endocrinol Metab 2009, 94, 1732-1739.

14. Rahaman M.A., Dea D., Handa S., Pal A., Sachdeva N., Ghosh T., et al.: Association of insulin-like growth factor (IGF)-1 gene polymorphisms with plasma levels of IGF-1 and acne severity. J Am Acad Dermatol 2016, 75, 768-773.

15. Melnik B.C., Schmitz G.: Role of insulin, insulin-like growth factor-1, hyperglycemic food and milk consumption in the pathogenesis of acne vulgaris. Exp Dermatol 2009, 18, 833-841.

16. Rodighiero E., Bertolani M., Saleri R., Pedrazzi G., Lotti T., Feliciani C., et al.: Do acne treatments affect insulin-like growth factor-1 serum levels? A clinical and laboratory study on patients with acne vulgaris? Dermatol Ther 2020, 33, 134-139.

17. Thiboutot D.M., Dréno B., Abanmi A., Alexis A.F., Araviiskaia E., Barona Cabal M.I., et al.: Practical management of acne for clinicians: an international consensus from the Global Alliance to Improve Outcomes in Acne. J Am Acad Dermatol 2018, 78 (2 Suppl 1), S1-S23.e1..

18. Dicembrini I., Bardini G., Rotella C.M.: Association between oral isotretinoin therapy and unmasked latent immuno-mediated diabetes. Diabetes Care 2009, 32, e99.

19. Corbetta S., Angioni R., Cattaneo A., Beck-Peccoz P., Spada A.: Effects of retinoid therapy on insulin sensitivity, lipid profile and circulating adipocytokines. Eur J Endocrinol 2006, 154, 83-86.

20. Berry D.C., Noy N.: All-trans-retinoic acid represses obesity and insulin resistance by activating both peroxisome proliferation-activated receptor beta/delta and retinoic acid receptor. Mol Cell Biol 2009, 29, 3286-3296.

21. Mercader J., Ribot J., Murano I., Felipe F., Cinti S., Bonet M.L., et al.: Remodeling of white adipose tissue after retinoic acid administration in mice. Endocrinology 2006, 147, 5325-5332.

22. Elmlinger M.W., Kuhnel W., Weber M.M., Ranke M.B.: Reference ranges for two automated chemiluminescent assays for serum insulinlike growth factor 1 (IGF-1) and IGF-binding protein- 3 (IGFBP-3). Clin Chem Lab Med 2004, 42, 654-664.

23. Williams H.C., Dellavalle R.P., Garner S.: Acne vulgaris. Lancet 2012, 379, 361-372.

24. Melnik B.C., Schmitz G.: Role of insulin, insulin-like growth factor-1, hyperglycaemic food and milk consumption in the pathogenesis of acne vulgaris. Exp Dermatol 2009, 18, 833-841.

25. Cappel M., Mauger D., Thiboutot D.: Correlation between serum levels of insulin-like growth factor 1, dehydroepiandrosterone sulfate and dihydrotestosterone and acne lesion counts in adult women. Arch Dermatol 2005, 141, 333-338.

Received: 19.04.2021

Accepted: 25.09.2021

Otrzymano: 19.04.2021 r.

Zaakceptowano: 25.09.2021 r.

\section{How to cite this article}

Doğan E.I.: Does isotretinoin have any effect on glucose metabolism, insulin growth factor-1 and insulin-like growth factor-3 binding protein? Dermatol Rev/Przegl Dermatol 2021, 108, 361-371. DOI: https://doi.org/10.5114/dr.2021.113154 